Status Report 2016-2019

\title{
Contemporary Researches and Issues Related to the Deccan Volcanism
}

\author{
AMIT KUMAR, SUCHARITA PAL and J P SHRIVASTAVA* \\ Department of Geology, University of Delhi, Delhi 110 007, India
}

(Received on 31 August 2019; Accepted on 30 September 2019)

\begin{abstract}
In the past few decades, late Cretaceous Deccan volcanism witnessed extensive researches, focused on nature, variety and genesis of magma, emplacement span [entail Cretaceous /Palaeogene $(\mathrm{K} / \mathrm{Pg})$ transition] and attendant faunal crisis; however several issues remain to be addressed. In this gamut, researches in the past five years have been reviewed, encompassing petrochemical, $\mathrm{Nd}-\mathrm{Sr}-\mathrm{Pb}$ isotopic, and geochronology studies to comprehend origin, age and duration of volcanism and attendant $\mathrm{K} / \mathrm{Pg}$ transition events. Low $/$ high $\mathrm{TiO}_{2}$ tholeiites of Deccan Traps and associated rocks from a rifted basin revealed existence of varied mantle sources for synchronously formed tholeiitic and alkaline magma involved sub-continental lithospheric mantle. Moreover, later magma type ascended with faster rate through the lithosphere and subsequently led to rapid gaseous release, accounted for the Cretaceous/Palaeogene boundary (KPB) mass extinction. Flow-by-flow palaeomagnetic measurements for the Mandla basalt revealed multiple magnetic polarity events: implying for C29n-C28rC28n magnetostratigraphy.

${ }^{40} \mathrm{Ar} /{ }^{39} \mathrm{Ar}$ ages for Mundwara and Sarnu-Dandali complexes assign polychronous emplacement, concomitant with the post-breakup of Indo-Madagascar. Both complexes show comparable evolution from early to late Cretaceous Period. U-Pb zircon age data based Deccan eruption rates when combined with the Chicxulub impact triggered seismicity, inferred four major eruptive phases, each lasted for $\leq 100 \mathrm{ka}$. In the second eruptive phase, Poladpur Formation eruption began tens of thousands of years before, but peaked out at $\mathrm{K} / \mathrm{Pg}$ mass extinction event. Consequently, carbonate dissolution, climatic cooling and late Maastrichtian global warming attendant to Deccan volcanism, induced ocean acidification which led to high environmental stress worldwide. Present review also covers applied aspects, including $\mathrm{CO}_{2}$ sequestration in Deccan basalt and suitability of silicic phase for nuclear waste disposal. Additionally, it ends-up with a note on future direction of researches in Deccan basalt.
\end{abstract}

Keywords: Deccan Volcanism; Cretaceous/Palaeogene Boundary; Palaeoenvironment; ${ }^{40}$ Ar $/{ }^{39}$ Ar Ages; InfraInter-Trappeans

\section{Introduction}

The Deccan Volcanic Province (DVP) represents one of the largest Continental Flood Basalt (CFB) provinces in the world (cf. 1.6, Ernst, 2014), covering an area of $0.51 \times 10^{6} \mathrm{~km}^{2}$ (Fig. 1), which records vast accumulation of basalt in a relatively short time span entailing the Cretaceous/Paleogene boundary (KPB). The Deccan volcanic activity initiated prior to the KPB, however, main episode occurred at $~ 300$ ka prior to or at the KPB itself(Schoene et al., 2015). Lithospheric versus asthenospheric contributions to Deccan Traps when compared to the Ethiopia-Yemen and Karoo continental flood basalt revealed similar parental magmas and fractionation trends (Natali et al., 2016). Such continental flood basalt represents similar zonal arrangement for the hottest and deepest picrite-basalt magmas in the central area and cooler and shallower basalts at the peripheral areas. Further, superheated picrite-basalt supposedly coeval with the alkaline-carbonatite complexes and rhyolitic differentiates often lie at the intersection of extensional lineaments and at the top of picrite-basalt lavas, respectively. Additionally, more or less unaffected mantle Sr-Nd isotopic values of picrate-basalt together with the lithospheric values of the peripheral basalt marked common geodynamic setting (Natali et al., 2016).

One of the thickest $(\sim 1.5 \mathrm{~km})$ Deccan Traps

*Author for Correspondence: E-mail: jpshrivastava.du@gmail.com 


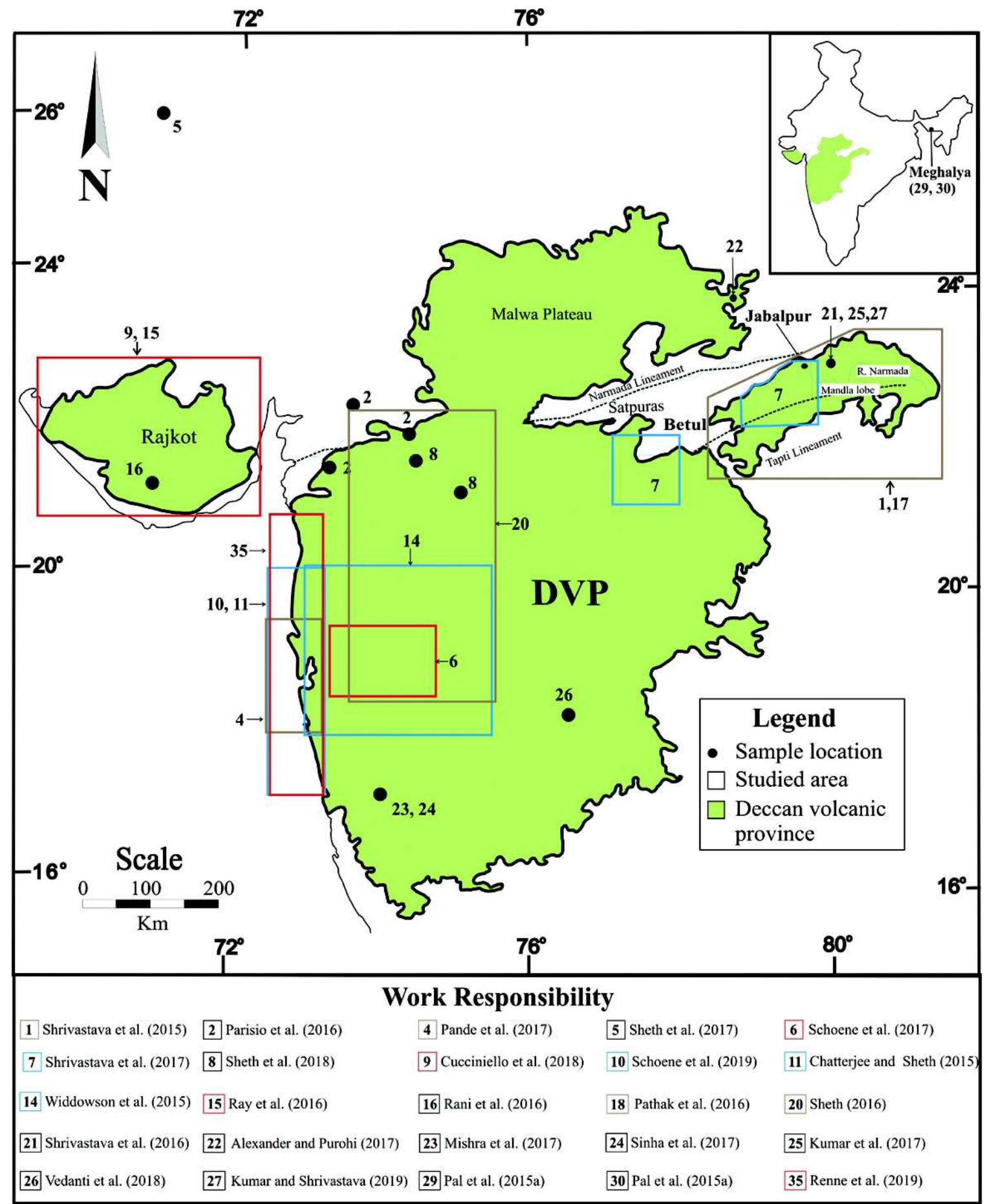

Fig. 1: Studies on Deccan volcanic province (green shaded area) carried out in the past five years shown with bold numbers enclosed within the parentheses. Work responsibility: (1) Shrivastava et al. (2015), (2) Parisio et al. (2016), (3) Font et al. (2016), (4) Pande et al. (2017), (5) Sheth et al. (2017), (6) Schoene et al. (2017), (7) Shrivastava et al. (2017), (8) Sheth et al. (2018), (9) Cucciniello et al. (2018), (10) Schoene et al. (2019), (11) Chatterjee and Sheth (2015), (12) Petersen (2015), (13) Rani et al. (2015), (14) Richards et al. (2015), (15) Widdowson et al. (2015), (16) Ray et al. (2016), (17) Rani et al. (2016), (18) Natali et al. (2016), (19) Pathak et al. (2016), (20) Sheth (2016), (21) Shrivastava et al. (2016), (22) Alexander and Purohit (2019), (23) Mishra et al. (2017), (24) Sinha et al. (2017), (25) Kumar et al. (2017), (26) Vedanti et al. (2018), (27) Kumar and Shrivastava (2019), (28) Prasanth et al. (2019), (29) Pal et al. (2015a), (30) Pal et al. (2015b), (31) Punekar et al. (2015), (32) Keller et al. (2017), (33) Chenming and Demin (2018), (34) Sprain et al. (2019) and (35) Renne et al. (2019). Note: references in italics refer to studies carried out on Deccan volcanism 
accumulation occurs in the Mahabaleshwer area of Western Deccan Volcanic Province (WDVP). In Koyna-Warna-Panchgani area, Sinha et al. (2017) and Mishra et al. (2017) reported 932 and $1251 \mathrm{~m}$ thick sub-surface lava packages, comprised of 30 and 46 lava flows, respectively. Although, stratigraphy of the lava flows, age and duration of volcanism in the Koyna-Warna-Panchgani area needs to be correlated with special reference to the main WDVP. Petrophysical and elastic studies of Vedanti et al. (2018) on $338 \mathrm{~m}$ thick sub-surface basalt package from Killari (KLR-1) borehole revealed presence of $\mathrm{FeO}(\sim 13.4 \mathrm{wt} \%)$ rich and $\mathrm{SiO}_{2}(47.8 \mathrm{wt} \%)$ poor Ambenali and Poladpur-like lava flows, characterized by a mean density of $2.91 \mathrm{~g} / \mathrm{cm}^{3}$ and $\mathrm{P}, \mathrm{S}$ wave velocities of 5.89 and $3.43 \mathrm{~km} / \mathrm{s}$, respectively. Overall, low velocity of $\mathrm{P}, \mathrm{S}$ waves observed in this sequence is ascribed to energy loss and intrinsic attenuation due to the prolific glass and high Fe contents and their intensely altered nature. Although, high order of attenuation is also noticed in few massive basalt types, either glassy or contain high proportion of chlorophaeite and other secondary silicates. Activities were mainly focused on Deccan volcanism and related fields (Fig. 1) and produced vast information (Table 1), however, to identify forthcoming research problems, an attempt has been made to review significant research contributions published in the journals of national and international repute in last five years. Outcome of the work is summarized and discussed under subsequent sections:

\section{Tholeiitic and Alkali Basalt-Carbonatite Associations}

The DVP dominantly composed of tholeiitic basalts (with a minor amount of alkaline, carbonatite, and silicic rocks) and is sub-divided into low $\left(\mathrm{TiO}_{2}<2.5 ; \mathrm{Ti} / \mathrm{Y}<\right.$ $500)$ and high $\left(\mathrm{TiO}_{2}>2.5 ; \mathrm{Ti} / \mathrm{Y}>500\right)$ Ti basalt types and inferred involvement of multiple mantle components assigning derivation from the depleted mantle sources (Prasanth et al., 2019). Alkaline rocks are commonly associated with the rift zones. Most of the researches carried out in the past five years were focused on the pericratonic rift basin in the Kutch area of northwestern India (Ray et al., 2016; Cucciniello et al., 2018). Both alkali and tholeiitic basalt types occur together in this area. Former is cropping out as an isolated, relatively small, eroded, cinder cone-like volcanic plugs within a linear belt in central part, whereas, later occurs in the form of subhorizontal flows in the southern part of the Kutch basin. Alkaline and tholeiitic magma types require varied degree of partial melting and mantle sources, however in a mantle plume scenario; alkaline magmatism precedes and possibly follows the main phase of tholeiitic magmatism. Parisio et al. (2016) established existence of varied mantle sources for the synchronously formed alkaline and tholeiitic magmas and require sub-continental lithospheric mantle involvement at the time of Deccan magmatism. Both alkaline and tholeiitic magmatism occurred during early and late phases, therefore, their derivation from same mantle source is highly unlikely. Ray et al. (2016) reported disc-shaped spinel peridotite mantle xenolithxenocrysts (of spinel lherzolite and spinel wehrlite compositions) bearing monogenetic alkali basaltic plugs (few connected to feeder dykes) and tholeiitic basalt lava flows from the fault controlled uplifted block of the Kutch basin. These observations were supported by prolifically present feeder dykes (with greater width) which contain large xenocrysts and xenoliths with thick alteration aureole around olivine xenocrysts. Commonality in the chemico-mineralogical attributes of these isolated alkali basalt is suggestive of cogenetic nature, implying for a common source, age and eruption mechanism. Alkali basalt contains, fractured olivine (Fo>90) fragments (Figs. 2 and 3) with embayed margins as xenocryst and less forsteritic $\left(\sim \mathrm{Fo}^{80}\right)$ olivine grains as phenocrysts (compared to groundmass grains). Alkali magma ascended through

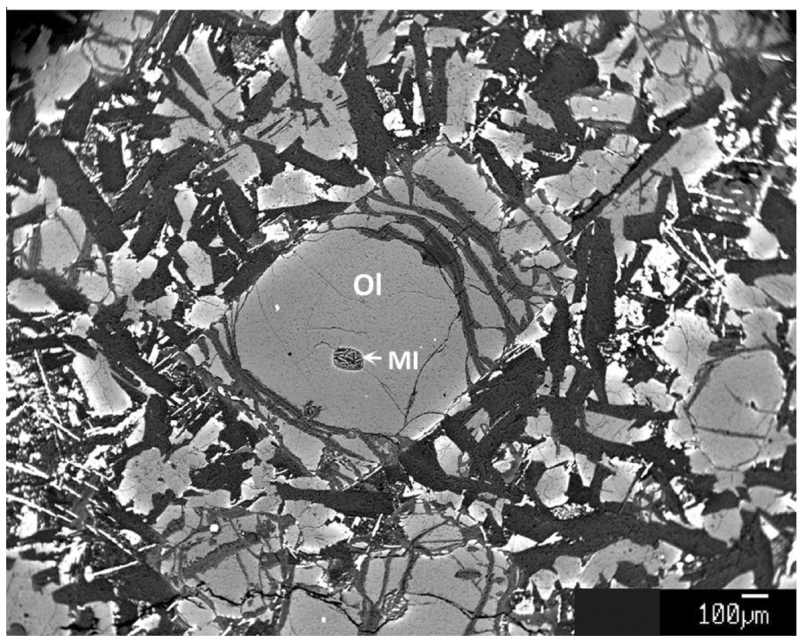

Fig. 2: Photomicrograph of olivine (OI) with alteration veins and melt inclusions (MI). Source: Chatterjee and Sheth (2015) 
Table 1: Location-wise summarized published work on Deccan volcanism and related fields

\begin{tabular}{lll}
\hline Locations & Summary of the work done & References
\end{tabular}

\section{Dating}

1. Post-K/PB younger ${ }^{40} \mathrm{Ar}-{ }^{39} \mathrm{Ar}$ ages of the Mandla lavas: Implications for the duration of Shrivastava et al. (2015) the Deccan volcanism,

2. $\quad{ }^{40} \mathrm{Ar} /{ }^{39} \mathrm{Ar}$ ages of alkaline and tholeiitic rocks from the northern Deccan Traps:

Parisio et al. (2016) implications for magmatic processes and the K-Pg boundary

3. Mercury anomaly, Deccan volcanism, and the end-Cretaceous mass extinction

Font et al. (2016)

4. $\quad{ }^{40} \mathrm{Ar} /{ }^{39} \mathrm{Ar}$ dating of the Mumbai tholeiites and Panvel flexure: intense 62.5Ma onshoreoffshore Deccan magmatism during India-Laxmi Ridge-Seychelles breakup

5. Recurrent Early Cretaceous, Indo-Madagascar (89-86 Ma) and Deccan (66 Ma) alkaline magmatism in the Sarnu-Dandali complex, Rajasthan: ${ }^{40} \mathrm{Ar} /{ }^{39} \mathrm{Ar}$ age evidence and geodynamic significance

6. U-Pb geochronology of the Deccan Traps and relation to the end-Cretaceous mass extinction

Pande et al. (2017)

Sheth et al. (2017) extinction

7. Feeder and post Deccan Trap dyke activities in the northern slope of the Satpura Mountain: Evidence from new ${ }^{40} \mathrm{Ar}-{ }^{39} \mathrm{Ar}$ ages

Schoene et al. (2015)

Shrivastava et al. (2017)

8. Geochemistry and ${ }^{40} \mathrm{Ar} /{ }^{39} \mathrm{Ar}$ geochronology of the Nandurbar Dhule mafic dyke swarm: Sheth et al. (2018) Dyke sill flow correlations and stratigraphic development across the Deccan flood basalt province

9. Mineralogy, geochemistry and ${ }^{40} \mathrm{Ar}-{ }^{39} \mathrm{Ar}$ geochronology of the Barda and Alech complexes, Saurashtra, northwestern Deccan Traps: early silicic magmas derived by flood basalt fractionation

10. $\quad \mathrm{U}-\mathrm{Pb}$ constraints on pulsed eruption of the Deccan Traps across the end-Cretaceous mass extinction

\section{Petrology and Geochemistry}

11. Origin of the Powai ankaramite, and the composition, P-T conditions of equilibration and evolution of the primary magmas of the Deccan tholeiites

12. End-Cretaceous extinction in Antarctica linked to both Deccan volcanism and meteorite impact via climate change

13. Natural glass from Deccan volcanic province: an analogue for radioactive waste form.

14. Triggering of the largest Deccan eruptions by the Chicxulub impact

15. The geochemistry of Indian bole horizons: palaeoenvironmental implications of Deccan intravolcanicpalaeosurfaces

16. Mantle xenolith-xenocryst-bearing monogenetic alkali basaltic lava field from Kutch Basin, Gujarat, Western India: Estimation of magma ascent rate

17. Long-term performance assessment of nuclear waste and natural glasses in the geological repository: A geochemical modelling

18. Comparison among Ethiopia-Yemen, Deccan, and Karoo continental flood basalts of central Gondwana: Insights on lithosphere versus asthenosphere contributions in compositionally zoned magmatic provinces

19. Tectonomagmatic setting of lava packages in the Mandla lobe of the eastern Deccan volcanic province, India: palaeomagnetism and magnetostratigraphic evidence

20. Giant plagioclase basalts: Continental flood basalt-induced remobilization of anorthositic mushes in a deep crustal sill complex

21. Geochemical Modeling and Experimental Studies on Mineral Carbonation of Primary Silicates for Long-term Immobilization of $\mathrm{CO}_{2}$ in Basalt from the Eastern Deccan Volcanic Province

22. At last! Giant plagioclase basalt from Sagar district

Petersen (2015)

Rani et al. (2015)

Richards et al. (2015)

Widdowson et al. (2015)

Ray et al. (2016)

Rani et al. (2016)

Natali et al. (2016)

Pathak et al. (2016)

Sheth (2016)

Shrivastava et al. (2016)

Alexander and Purohit (2019) 
23. A $1251 \mathrm{~m}$-thick Deccan Flood Basalt Pile Recovered by Scientific Drilling in the Koyna Region, Western India

24. The Subsurface Megascopic Characteristics of Basalt and Basement Rocks from Koyna-Warna Area of Maharashtra, India

25. Mineral carbonation reactions under water-saturated, hydrothermal-like conditions and numerical simulations of $\mathrm{CO}_{2}$ sequestration in tholeiitic basalt of the Eastern Deccan Volcanic Province, India

26. Ultrasonic P- and S-Wave Attenuation and Petrophysical Properties of Deccan Flood Basalts, India, as Revealed by Borehole Studies

27. Thermodynamic Modelling and Experimental Validation of $\mathrm{CO}_{2}$ Mineral Sequestration in Mandla Basalt of the Eastern Deccan Volcanic Province, India

28. Tholeiitic basalts of Deccan large igneous province, India: An overview

Mishra et al. (2017)

Sinha et al. (2017)

Kumar et al. (2017)

Vedanti et al. (2018)

Kumar and Shrivastava (2019)

Prasanth et al. (2019)

\section{Lava-flow stratigraphy}

29. Polycyclic aromatic hydrocarbon compound excursions and $\mathrm{K} / \mathrm{Pg}$ transition in the late Cretaceous-early Palaeogene succession of the Um Sohryngkew river section, Meghalaya

30. Physils and organic matter-basepalaeoenvironmental records of the K/Pg boundary transition from the late Cretaceous-early Palaeogene succession of the Um-Sohryngkew River section of Meghalaya, India

31. A multi-proxy approach to decode the end-Cretaceousmass extinction

32. Environmental changes during the Cretaceous-Paleogene mass extinction and Paleocene-Eocene Thermal Maximum: Implications for the Anthropocene

33. Study on the Relationship Between Deccan LIPs and Chicxulub Crater Based on "Collisions Aggregation Effect"

34. The eruptive tempo of Deccan volcanism in relation to theCretaceous-Paleogene boundary

Pal et al. (2015a)

Pal et al. (2015b)

Punekar et al. (2015)

Keller et al. (2017)

Chenming and Demin (2018)

Sprain et al. (2019)

35. State shift in Deccan volcanism at the Cretaceous-Paleogene boundary, possibly induced by impact

Renne et al. (2019)

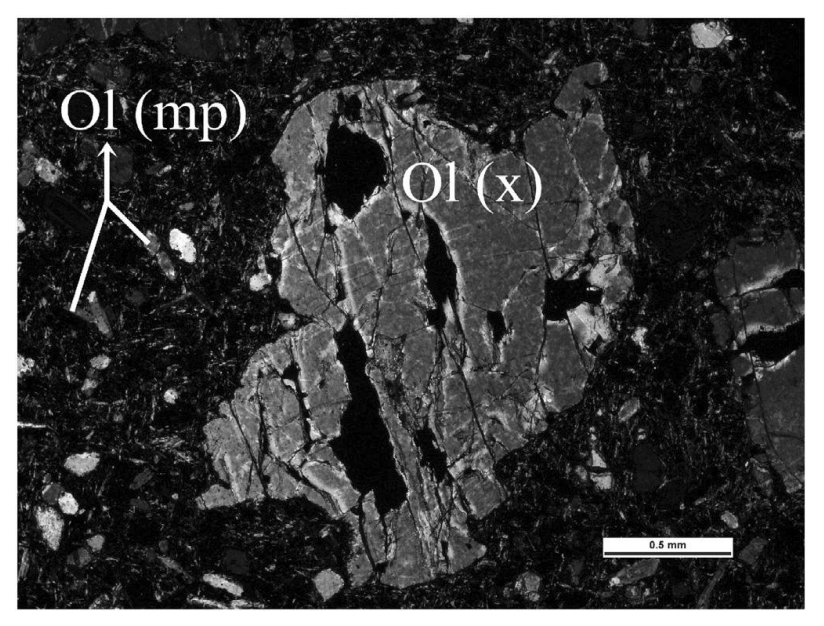

Fig. 3: Photomicrograph of alkali basalt type from the Kutch area showing olivine xenocryst with fractures filled up with glassy groundmass. Microphenocrysts and groundmass olivine grains are also present along with the olivine xenocryst. Abbreviations: Ol(x)olivine xenocryst; Ol(mp)-microphenocryst of olivine. Source: Ray et al. (2016)

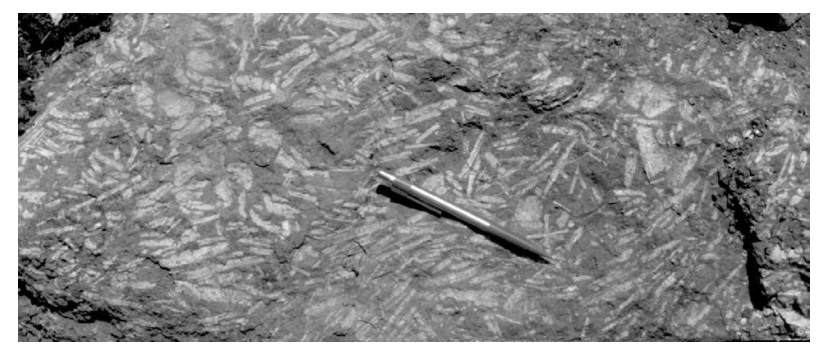

Fig. 4: Giant plagioclase basalt from BijasanGhat showing well-developed, lath-shaped plagioclase megacrysts $(5 \mathrm{~cm}$ in length). Source: Sheth et al. (2016)

the lithosphere with faster rate, where mantle xenoliths were broken-up into smaller fragments. These processes were considered as major causative factors for the $\mathrm{K} / \mathrm{Pg}$ mass extinction. Chatterjee and Sheth (2015) studied ankaramite from Powai in the Bombay area which contains zoned olivine crystals. Primary magmas for this area as well as voluminous Ambenali and Mahabaleshwar Formation tholeiites in the 
Western Ghats representing primitive tholeiites $(\mathrm{MgO}$ 8.74-11.77 wt \%, Mg\# 70-74). Such magma types last equilibrated with the mantle peridotite at a temperature and pressure ranging between $1268-1332^{\circ} \mathrm{C}\left( \pm 12^{\circ} \mathrm{C}\right)$ and $8.0-13.0 \mathrm{~kb}( \pm 0.8 \mathrm{~kb})$ corresponding to the depth between $30-49 \mathrm{~km}( \pm 3 \mathrm{~km})$, respectively. Moreover, primary magmas originated by $₫ 5 \%$ batch melting of the mantle and these magma types underwent olivine gabbro fractionation. As a result, mafic cumulate piles $(\mathrm{Ol}+\mathrm{Cpx}+\mathrm{Opx})$ produced at the bottom of magma chambers. Later tholeiitic magma batches penetrated cumulate piles which led to the formation of cumulate rich ankaramite and underwent dissolution of the orthopyroxene and subsequent crystallization of augite, olivine, and plagioclase. The voluminous Ambenali and Mahabaleshwar tholeiites of the Western Ghats last equilibrated with the spinel lherzolite mantle which was neither Fe rich nor anomalously hot.

\section{Giant Plagioclase Basalt}

The Giant Plagioclase Basalt (GPB) containing long $(\sim 5 \mathrm{~cm}$ ) plagioclase megacrysts (Fig. 4 ) attending as a marker horizon for the upper of the Deccan stratigraphic formational boundaries. These megacrysts form anorthositic mushes embedded within the ferrodioritic interstitial glassy groundmass. On the basis of unusual occurrence of such type of basalt, Sheth (2016) proposed a model, where residency period of $\sim 15 \mathrm{ka}$ in a deep crustal sill complex was postulated for the magma to grow plagioclase megacrysts before being erupted. Of late Alexander and Purohit (2019) reported GPB from lava flows in the northeastern basalt in the Sagar area of Madhya Pradesh. However, stratigraphic correlation between these two GPB horizons and details pertaining to lava flows (which lie immediately below as well as above) is lacking in the literature.

\section{DVP Associated Anorogenic, Intra-plate Silicic Magmatism}

Cucciniello et al. (2018) recognized advanced fractional crystallization of basaltic magmas, crustal assimilation coupled with fractional crystallization, partial melting of basalt and anatexis of old basement crust as important processes responsible for their formation. $\mathrm{Sr}-\mathrm{Nd}-\mathrm{Pb}$ isotopic data in conjunction with the geochemical data, assigned process of multiple magma injections to the ENE-WS trending Nandurbar-
Dhule tholeiitic dyke swarms (Sheth, 2018). These dykes served as feeders to few Western Ghats and Saurashtra lavas, located $\sim 200 \mathrm{~km}$ away from the dyke swarms. Moreover, compositionally distinct (high $\mathrm{TiO}_{2}$ ), but, majority of them are isotopically akin to Mahabaleshwar and Panhala Formations of the upper Western Ghats that lie within a narrow isotopic array and represent distinctive chemical signatures somewhat comparable to distant $(\sim 600 \mathrm{~km})$ dykes, sills, and lavas of the Pachmarhi, Shahdol, and Mandla areas in the Satpura and Narmada regions in the eastern Deccan Traps. Distinctive isotopic signatures of Nandurbar-Dhule tholeiitic dyke swarms were somewhat similar to the dykes, sills, and lavas of the Pachmarhi (Shrivastava et al., 2008; Kumar and Shrivastava, 2009) and Mandla (Shrivastava, 2014) areas, located $\sim 900 \mathrm{~km}$ to the east, thus, justify a separate entity of eastern Deccan lava stratigraphy.

\section{Age and Duration of Deccan Volcanism}

Earlier reported Deccan basalt ages recognized that bulk of magma was emplaced within a period of 67 $65 \mathrm{Ma}$, however, with the exception of some early alkaline activity in the Cambay graben at $69 \mathrm{Ma}$. But, Shrivastava et al. (2015) assigned significantly younger ages of 63-65 Ma (weighted mean age of $64.21 \pm 0.33 \mathrm{Ma}$ ) to the stratigraphically controlled $900 \mathrm{~m}$ thick Mandla lobe succession (which contains 37 lava flows) on the eastern margin of Deccan volcanic province. New ages are consistent, however, with the geochemical correlation of the Mandla lobe lavas with the uppermost succession (PoladpurAmbenali-Mahabaleshwar Formations) of southwestern Deccan Traps, indicated that this post KPB youngest phase of flood basalt activity erupted over much of the province. The Deccan volcanic activity occurred in several phases - an earlier phase was accountable for the formation of great western succession of lava flows, whereas, later phase resulted in the formation of terminal lava flows of the southwest region and entire succession of the Mandla lobe in the east (Shrivastava et al., 2015). The post-KPB younger ${ }^{40} \mathrm{Ar}-{ }^{39} \mathrm{Ar}$ ages of the Mandla lavas have serious implications on the duration of Deccan volcanism (Shrivastava et al., 2015). A large number of Deccan basalt dykes associated with the east-west trending Narmada-Tapti-Son lineaments are supposedly synchronous with Deccan volcanic eruptions. But, in the northern slope of Satpura 
Mountain range ( $\sim 800 \mathrm{~km} \mathrm{NE}$ of the Western Ghats escarpment), Shrivastava et al. (2017) recognized feeder and post-Deccan Traps dyke activities solely on the basis of new ${ }^{40} \mathrm{Ar}-{ }^{39} \mathrm{Ar}$ ages of $66.56 \pm 0.42$ and $56.95 \pm 1.08 \mathrm{Ma}$ from two distinct dykes (Fig. 5) which cut across the lava flows near Mohpani and Olini villages, respectively. The new age data on the Mohpani dyke yielded an age of $66.56 \pm 0.42 \mathrm{Ma}$, which is earlier to or contemporaneous with the nearby Mandla lavas. It is evident that the lava flowed through major fractures/faults and emplaced as dykes and served as conduits for the lava flows. Thus, dykes possibly served as feeders. The new ages are also consistent with geochemical correlation of the Mandla lavas and with uppermost Poladpur, Ambenali and Mahabaleshwar Formation lavas of the southwestern Deccan (Shrivastava et al., 2014). The dyke near

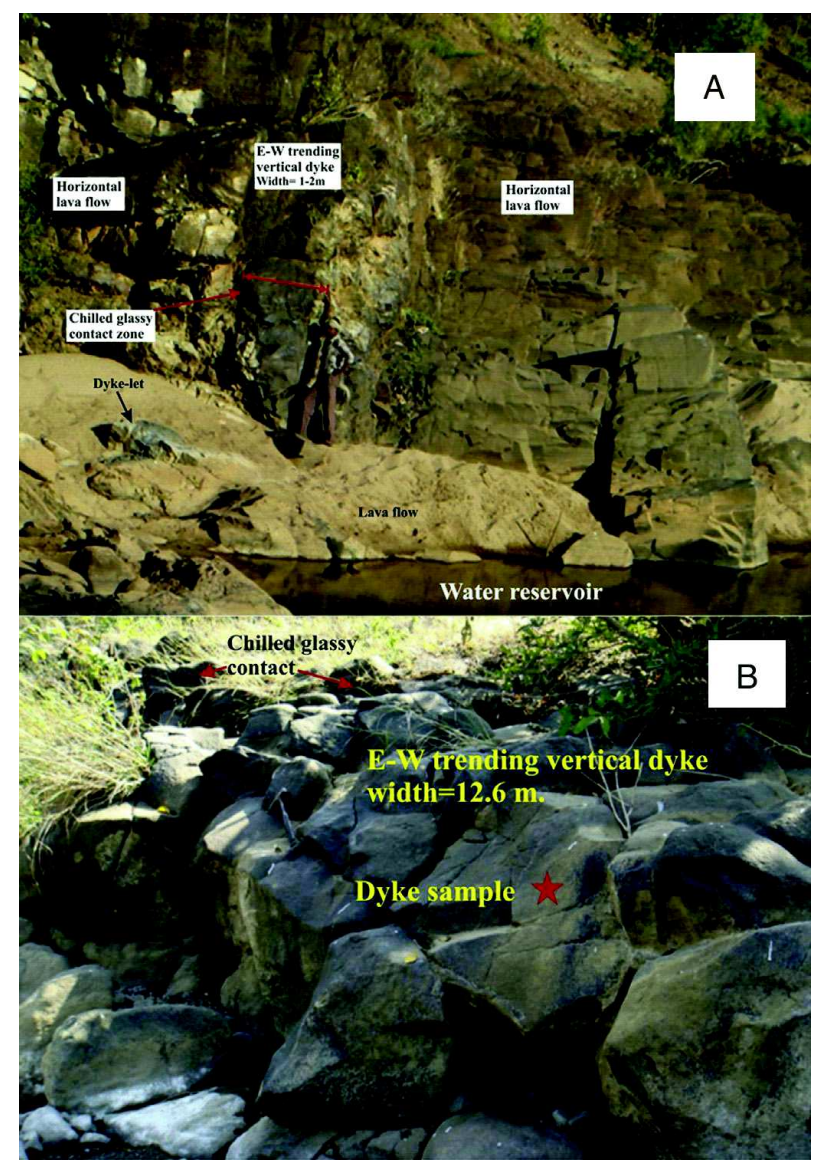

Fig. 5: Field photographs showing dykes located (a) near Olini (sample P7) and (b) Mohpani villages (sample $P 18)$ in Betul area. Chilled contact zones vary in thickness from 3 to $8 \mathrm{~cm}$, lying between the dyke and lava flows marked in the photograph. Source: Shrivastava et al. (2017)
Olini village represents an age of $56.95 \pm 1.08 \mathrm{Ma}$ which is much younger and represents the terminal stage of dyke activity.

Recent ${ }^{40} \mathrm{Ar}-{ }^{39} \mathrm{Ar}$ ages from the northern portion of the DVP provided new constraints on the relationship between two magma series and on the evolution of Deccan magmatism (Parisio et al., 2016) and further assigned an age of $65.86 \pm 1.68 \mathrm{Ma}$ for the first stage of magmatism in the Rajpipla area. Besides this, the Rajpipla basalt and Pavagadh rhyolite $(64.9 \pm 0.8 \mathrm{Ma})$ represent a maximum and minimum duration of the tholeiitic Deccan magmatism of $3 \mathrm{Ma}$ and $<1 \mathrm{Ma}$, respectively. Conversely, alkaline magmatism lasted within $4 \mathrm{Ma}$, starting from $69.62 \pm$ $0.08 \mathrm{Ma}$ to $65.25 \pm 0.29 \mathrm{Ma}$. Significantly, recalculated ${ }^{40} \mathrm{Ar}-{ }^{39} \mathrm{Ar}$ ages suggested that the magmatic activity started at the boundary between magnetic chrons C31r and C31n with the emplacement of the Sarnu Dandali and Mundwara complexes, and Deccan magmatism lasted at least $4 \mathrm{Ma}$. Moreover, ${ }^{40} \mathrm{Ar}-{ }^{39} \mathrm{Ar}$ ages of Parisio et al. (2016) for the Pavagadh complex and Phenai Mata alkaline rocks indicated incidence of late-phase of magmatism in the northern Deccan volcanic province. ${ }^{40} \mathrm{Ar} /{ }^{39} \mathrm{Ar}$ ages of Pande et al. (2017) for the Mumbai tholeiitic and Panvel flexure flows, and post-flexure dykes yielded similar ages of $62.5 \mathrm{Ma}$ and suggested rapid formation of Panvel flexure at 62.5 Ma. These observations are congruent with the Dongri rhyolite flow ages of 62.5 Ma from the uppermost part of Mumbai volcanic sequence. Post-rift magmatism ages of 60.8-60.9 and 60-61 Ma assigned to the Manori trachyte and Gilbert Hill basalt in the Mumbai area, respectively. Thus, these units were coeval with the rift-to-drift transition of breakup between the Seychelles and the Laxmi Ridge-India, thus clearly recognize pre-, syn- and postrift Deccan magmatism associated with the breakup of Seychelles from the Laxmi Ridge and India. The longest $(\sim 79 \mathrm{~km})$, Nandurbar-Dhule tholeiitic dyke swarms in the Deccan Traps represent ${ }^{40} \mathrm{Ar} /{ }^{39} \mathrm{Ar}$ ages of 67.06-63.43 $\pm 0.48 \mathrm{Ma}$, suggestive of $\geq 2.5$ emplacement span under regional crustal extension (Sheth et al., 2018).

Sheth et al. (2017) reported new ${ }^{40} \mathrm{Ar} /{ }^{39} \mathrm{Ar}$ ages of 88.9-86.8 Ma from the Sarnu-Dandali alkaline complex, Rajasthan and suggested that the syenite, nephelinite, phonolite and rhyolite rocks were much older than Deccan basalt (66 Ma) rock types present 
within the complex, thus, assigned two diverse emplacement episodes entailing a time lag of $\sim 20$ $\mathrm{Ma}$ in the late Cretaceous Period (for these two distinctive rock groups). Pande et al. (2017) on the basis of ${ }^{40} \mathrm{Ar} /{ }^{39} \mathrm{Ar}$ ages suggested polychronous emplacement for the Mundwara alkaline complex, located $\sim 120 \mathrm{~km}$ southeast of Sarnu-Dandali in Rajasthan. Moreover, 84-80 Ma ages obtained from the Mundwara alkaline complex represents postbreakup stages of the Indo-Madagascar. Thus, akin to the Mundwara complex, Sarnu-Dandali complex is also polychromous in nature and characterized by periodically replenished alkaline magma. Temporally, both the complexes show comparable evolution from early to late Cretaceous period and spatially record Indo-Madagascar flood basalt volcanism to northwestern India. Of late, Schoene et al. (2019) estimated Deccan eruption rates using $\mathrm{U}-\mathrm{Pb}$ zircon as chronometer. They recognized four major eruptive phases (Fig. 6); each lasted for $₫ 00 \mathrm{ka}$ and separated by periods of relative volcanic quiescence. Moreover, one of the phases initiated tens of thousands of years prior to both the bolide impact and the K/Pg extinction. Coincidental with the second major eruptive phase,

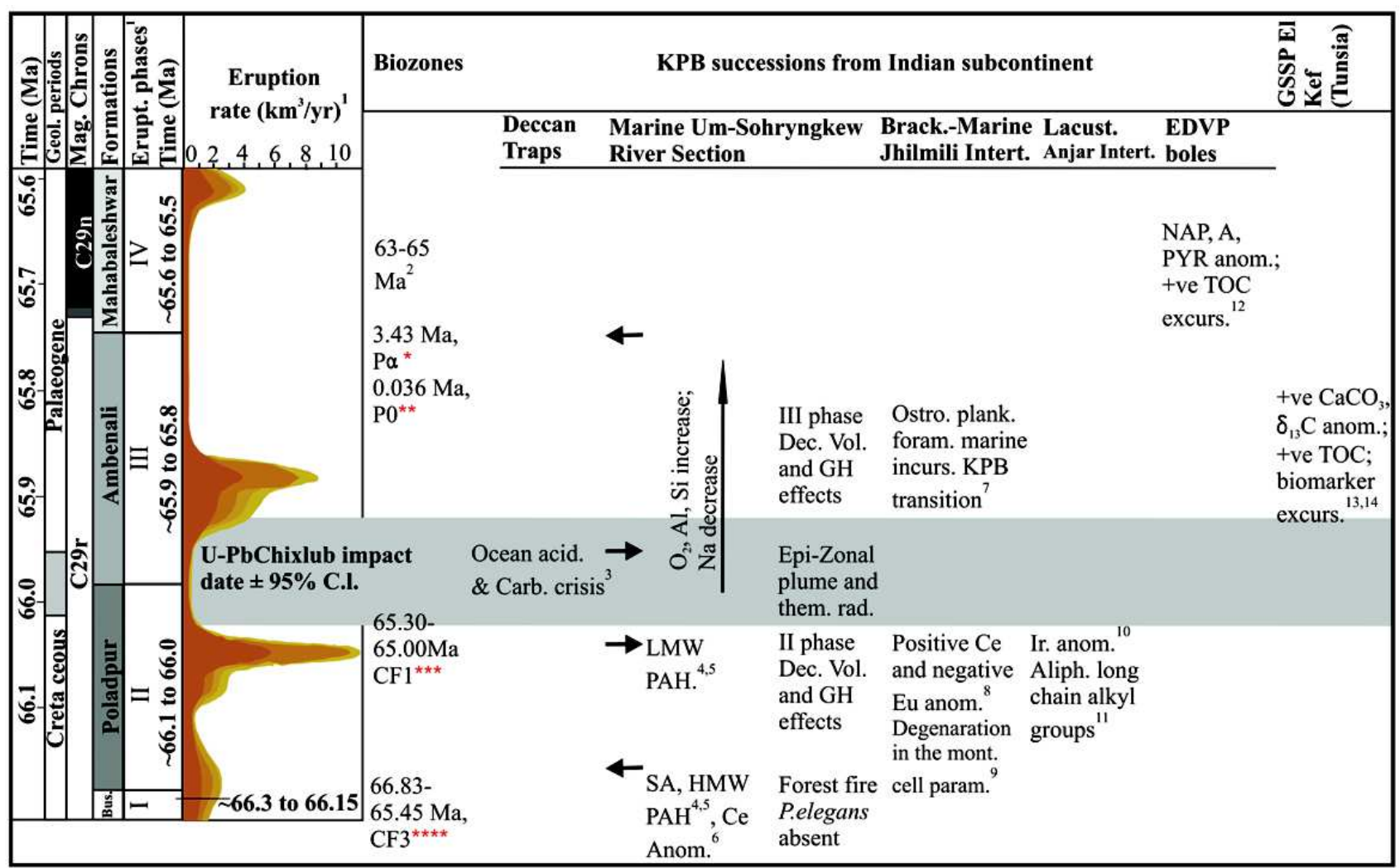

Fig. 6: Major eruptive phases, timing of the $\mathrm{K} / \mathrm{Pg}$ transition events and organo-molecular compounds (associated with the marine Um-Sohryngkew river section) calibrated with respect to biozonation and GSSP EI kef (Tunisia) sections (as a reference) further correlated with the Jhilmili and Anjarintertrappeans and EDVP bole beds successions. Data Source: Bhandari et al. (1987); Mukhopadhyay (2008, 2009, 2010, 2012a,b, 2013); Shrivastava et al. (2013); Pal et al. (2015a-c), where, $*=$ Parvularugoglobigerinaeugubina, $* *=$ Guembelitriacretacea, $* * *=$ Plummeritahantkeninoides, $* * * *=$ Pseudoguembelinahariaensis, 1 = Schoene et al. (2019); 2 =Shrivastava et al. (2015), 3 = Punekar et al. (2016), 4, $5=$ Pal et al. $(2015$ a,b), 6 = Shrivastava et al. (2013), $7=$ Keller et al. $(2009), 8=$ Pal et al. $(2013), 9=$ Pal et al. $($ In press a), $10=$ Bhandari et al. (1987), 11 = Shrivastava and Ahmad (2005); 12 = Pal et al. (In press b), 13 = Keller and Lindinger (1989), $14=$ Gross (2017). Abbreviations: Geol. Periods $=$ Geological Periods, Mag. Chrons= Magnetic chrons, Erupt. $=$ eruption, Bus. $=$ Bushe, Ocean acid. $=$ Oceanic acidification, Carb. crisis $=$ carbonate crisis, $L M W P A H=l o w$ molecular weight polycyclic aromatic hydrocarbon compounds, $S A=$ short chain n-alkanes, $H M W P A H=$ high molecular weight polycyclic aromatic hydrocarbon compounds, Ce anom. $=$ Ce anomaly, Dec. $=$ Deccan, Vol. $=$ Volcanism, GH effects $=$ Greenhouse effects, P. elegans $=$ Pseudotextulariaelegans, Brack.-Marine $=$ Brackish-Marine, Intert. $=$ Intertrappean, Ostro. $=$ Ostrocod, Plank. Foram. $=$ Planktonic foraminifera, incurs. $=$ incursion, Mont. $=$ montmorillonite, Lacust. $=$ Lacustrine, Ir. anom. $=$ Iridium anomaly, Aliph. $=$ aliphatic, $N A P=$ napthalene, $A=$ anthracene, $P y r=$ pyrene, $+v e=$ positive. Symbols: and denotes transgression and regression, respectively 
Poladpur Formation eruption began tens of thousands of years before, but, peaked out at the $\mathrm{K} / \mathrm{Pg}$ mass extinction event which continued after it, but in a subdued manner. Finding out Chicxulub impact signature (if any) may provide a precise stratigraphic reference point within Deccan stratigraphy.

\section{Palaeomagnetism and Magnetostratigraphy}

In the Mandla area of Eastern Deccan Volcanic Province (EDVP), flow-by-flow palaeomagnetic measurements (Pathak et al., 2016) for the 37 lava flows (from the $\sim 900 \mathrm{~m}$-thick, isolated lava pile) revealed multiple magnetic polarity events: implying for the C29n-C28r-C28n magnetostratigraphy. However, based on recent palaeomagnetic data from Deccan dyke swarms of the Mumbai area, Basavaiah et al. (2018) suspected more reversals than three Chrons (n-r-n) flow magnetostratigraphy. These results when traced out from section to section, maintaining the order of superposition, resolved that the lava packages of contrasting characters are juxtaposed near Deori area. In Dindori and also towards south, the distinct lava packages are juxtaposed and explained by the presence of four normal post-Deccan faults in the Nagapahar, KundamDeori, Dindori and Badargarh-Amarkantak sectors, thus, justify structural complexity with the vertical shifts of 150-300 m. To some extent, observed magnetic polarity bias (transitional direction) might be the result of combined effects of tectonic disturbance in the area, lesser availability of the unaltered lava flows and their altitude based correlation. Considering the highly wavy palaeo-surfaces and faulting due to postDeccan isostatic adjustments over a distance of $800 \mathrm{~km}$ along the strike length, there is a possibility of disorder in the stratigraphic heights of lava packages, which, therefore, constrains the altitude-based correlation of lava packages over such a vast area.

Magnetostratigraphic correlation of the Mandla lavas with that of the main DVP is mainly based either on: (a) magnetic polarity correlation as a function of altitude or (b) available ${ }^{40} \mathrm{Ar} /{ }^{39} \mathrm{Ar}$ ages of the Mandla lava flows. Later correlation is solely based on new ${ }^{40} \mathrm{Ar} /{ }^{39} \mathrm{Ar}$ ages (Shrivastava et al., 2015) which are consistent with the GPTS (Cande and Kent, 1995; Gradstein et al., 2012), thus, pointing to the idea that the entire Mandla lava package were laid down in the chrons $\mathrm{C} 29 \mathrm{n}-\mathrm{C} 28 \mathrm{r}-\mathrm{C} 28 \mathrm{n}$. The later correlation seems to be more reliable as it lies well within the GPTS of Gradstein et al. (2012). As compared to the southwestern lavas, Mandla lavas erupted at different times. In view of the palaeomagnetic results, it is suggested that the Mandla lavas erupted from different feeder system(s). Proposed C29n-C28r-C28n magnetostratigraphy of the Mandla lavas revealed that they are significantly younger than the majority of main DVP lava sequences documented from the Western Ghats.

Magnetic chron reversals in conjunction with field and chemical data supported these findings (Pathak et al., 2016). Further, compositionally these lavas are akin to Bushe, Poladpur, Ambenali and Mahableshwar Formational lavas, and follow the same stratigraphic order as in the Western Ghats. Alternating field (AFD) and thermal demagnetizations (THD) isolate the normal mean direction of the Mandla lobe. The Virtual Geomagnetic Pole (VGP) position determined for these lavas, when compared to the Deccan Super Pole, indicates concordance with the main DVP, thus, assigning eruption ages close to the KPB for the eastern and western Deccan Traps.

\section{Deccan Volcanism and K/Pg Transition Events}

Punekar et al. (2016) discussed excessive amount of $\mathrm{CO}_{2}$ and $\mathrm{SO}_{2}$ release during the most violent phase of Deccan volcanism introduced into the atmosphere which was the causative factor for carbonate crisis in the oceans and severe stress to the marine calcifiers, ultimately led to the mass extinction (Fig. 6). Highly stressed environment initiated for planktic foraminifera is evidenced by $\sim 50 \mathrm{~cm}$ below the KPB layer at Bidart (France) and Gamsbach in Austria and $\sim 4.5$ $\mathrm{m}$ below the KPB at Elles in Tunisia. Moreover, corresponding interval in India documented stronger carbonate dissolution effects in the intertrappean sedimentary units which lie between the longest lava flows and culminated with the mass extinction. Based on these observations, Punekar et al. (2016) inferred that the widespread dissolution event stratigraphically matches with the climatic cooling and followed by the late Maatrichtian global warming. These major events perhaps were attendant to Deccan volcanism induced ocean acidification (Fig. 6). Further, late Maastrichtian CF1 zone in the former two areas revealed events within the latest $\sim 160 \mathrm{ka}$ of late Maastrichtian and considered as critical as far as role 
of the Deccan volcanism in global high stress environments is concerned. Sudden rise in temperature $\left(>140^{\circ} \mathrm{C}\right)$ during the formation of illite in the upper part of biozone CF3 is comparable to the KPB layer of Caravaca section of Spain (Pal et al., 2015a). Moreover, humid tropical to arid-semiarid climatic and thermal variation across the succession were linked to the contemporaneous Deccan volcanic activities. Total organic carbon together with the short chain $n$-alkane and fatty acid spikes (Fig. 6) are concomitant with the sudden rise in the palaeotemperature $\left(>140^{\circ} \mathrm{C}\right)$ of the yellowish brown organic rich clay layer in biozone CF3 (Pal et al., 2015b; 2019a). These organic macro-molecules reflected global fire, induced by the heat supplied by late Cretaceous Deccan extrusions initiated prior to the $\mathrm{KPB}$, however, the main episode of Deccan volcanic activity occurred $\geq 300 \mathrm{ka}$ earlier or after the KPB itself. Punekar et al. (2016) provided evidence of Deccan-related environmental changes at the onset of $\mathrm{K} / \mathrm{Pg}$ mass extinction from Bidart section (France). In this area, the sedimentary layer which lie immediately $\sim 80 \mathrm{~cm}$ below and $\sim 50 \mathrm{~cm}$ above the KPB layer contains anomalously high $\mathrm{Hg}$ concentrations ( $>2$ orders of magnitude) coincidental with the low magnetic susceptibility interval (Font et al., 2016). The $\mathrm{K} / \mathrm{Pg}$ mass extinction is universally attributed to the Chicxulub impact; however Deccan volcanism contributed to as a major factor (Keller et al., 2017). Although, the $\mathrm{Hg}$ anomalies pointed out that the major Deccan eruptions accelerated during last $10 \mathrm{ka}$ and reached to its maxima which led to mass extinction. Thus, Chicxulub asteroid impact (Mexico) and gigantic Deccan volcanic eruptions were proposed as the major causes for the endCretaceous mass extinction, including sudden demise of nonavian dinosaurs. But, high resolution $\mathrm{U}-\mathrm{Pb}$ zircon ages determined by Schoene et al. (2015) provided an idea that the main phase of eruptions initiated $\sim 250$ ka prior to the KPB, where $>1.1$ million $\mathrm{km}^{2}$ of basalt erupted in $\sim 750 \mathrm{ka}$. These results are consistent with the idea that the Deccan volcanism contributed to the latest Cretaceous environmental change and the biologic turnover that culminated in the marine and terrestrial mass extinctions. However, the main phase of Deccan volcanism occurred at 66 Ma, but, its activity started $\sim 0.5$ Ma prior to and terminated after the KPB and the Chicxulub impact dated at $66.04 \pm 0.09 \mathrm{Ma}$ and $66.04 \pm 0.05 \mathrm{Ma}$, respectively (Sprain et al. 2019). A noticeable $7.8 \pm$ $3.3^{\circ} \mathrm{C}$ warming which was synchronous with the onset of Deccan volcanism, however, a second, smaller warming was at the time of meteorite impact (Petersen et al., 2016). Although, eruption pattern, as well as rate of Deccan volcanism at the KPB was primarily affected by the Chicxulub impact (Renne et al., 2015; Richards et al., 2015). To understand relationship of the Deccan volcanism across the KPB at Um Sohrynkew and Jhilmili sections in India, Sial et al. (2017) employed $\mathrm{Hg}, \mathrm{Hg} / \mathrm{TOC}$ and $\mathrm{Al}_{2} \mathrm{O}_{3}$ as proxies for volcanism and recorded true $\mathrm{Hg}$ anomalies and three prominent $\mathrm{Hg}$ /TOC spikes: (1) within the CF2 planktic foraminiferal biozone, (2) at the KPB, and (3) within the P1a planktic foraminiferal sub-zone of the former as well as in the Jhilmili sections. They further concluded that $\mathrm{Hg}$ anomalies possibly attributed to strong volcanic incidences of the Deccan phase-2 (started $250 \mathrm{ka}$ before the KPB and lasted for $750 \mathrm{ka}$ ). These incidences were accountable for prolific sulfuric aerosols and carbon dioxide emissions. Moreover, $\mathrm{Hg}$ isotopic spike 2 in Meghalaya KPB layer, spike 1 in CF2 biozone and spike 3 in Jhilmili are consistent with the peak volcanic $\mathrm{Hg}$ emissions, thus $\mathrm{Hg}$ enriched in paleoenvironment at three distinct stages during the Deccan phase-2. However, Mukhopadhyay et al. (2017) pointed out that the KPB reported by Sial et al. (2016) is not compatible with the existing planktonic foraminiferal succession across $\mathrm{K} / \mathrm{Pg}$ boundary in the Um Sohryngkew River section, Meghalaya India. Owing to the meteorite impact and the Deccan Traps formed by the collisions, aggregation effect of the Chicxulub crater impact triggered massive mass extinctions (at $65 \mathrm{Ma}$ of the $\mathrm{K} / \mathrm{Pg}$ boundary) and accelerated the Indian Plate drift (Chenming et al., 2018). The eruptive pulse of Deccan volcanism studied with reference to the KPB concluded that the late Cretaceous records of climate change coincided temporally not with the major and most violent phase, but, with the eruption of smallest Deccan Trap phases (Sprain et al., 2019). They opined that either the release of climate-modifying gases was not directly related to eruptive volume or Deccan Traps volcanism, therefore, Deccan volcanism was not the source of late Cretaceous climate change. However, diverse ideas emerged out of the studies (Sprain et al. 2019; Schoene et al., 2019) on relative timing of Deccan Traps emplacement and mass extinction. On the basis of 
age data-sets, the stratigraphic position of KPB was assigned within Deccan Traps stratigraphy. But the subtle difference in placement significantly alters the balance of accountability between the bolide impact and the Deccan volcanic events (Burgess, 2019). Thus, finding out Chicxulub impact signature (if any) may provide a precise stratigraphic reference point within Deccan stratigraphy.

\section{Infra/-interflow Volcanic Bole Beds}

Widdowson et al. (2015) discussed Deccan intravolcanic bole horizons, representing weathered products formed at the time of major hiatuses between two successive major volcanic episodes. Both bole beds and altered lavas represent a comparatively early stage of weathering because residual elements, such as $\mathrm{Al}$ and $\mathrm{Fe}$ are closer to the fresh basalt than the laterite. Nevertheless, there is clear evidence in support of significant chemical alteration as the more mobile elements such as $\mathrm{Ca}$ and $\mathrm{Na}$ have been substantially removed. Several Deccan Traps associated bole beds are in fact weathered pyroclastic material, where pyroclastic content of the basaltic succession is very large. A significant pyroclastic input during Deccan eruptions has important palaeoenvironmental implications for the fate of late Cretaceous fauna and flora that existed in the Peninsular India.

Red bole horizons formed by pervasive subaerial weathering of the previously exposed igneous materials together with the locally associated lacustrine and fluvial sediments. Yet, unlike the lava sequences, intertrappean bole horizons have received little geological attention, although, it is accepted that the formation of these weathering horizons temporally represents greater part of the history of $\mathrm{CFB}$ provinces. Geochemical study of the weathered bole horizons established the role of elemental mobilization during chemical weathering, but indicated that the geochemical data cannot always be reconciled with the established patterns of elemental depletion (typical of alteration of a basaltic precursor). In addition, thin sections indicate that the fine-grained portions of some boles contain glass shards and fresh phenocrysts of a pyroclastic origin. Though, the Deccan intertrappean surfaces, all that resulted from the same endogenetic process (namely the development of lava fields during flood basalt volcanism), the saprolitic and pyroclastic boles recorded two different types of palaeoenvironmental conditions. The former group formed by protracted, in-situ alteration of the lava surfaces during the periods of volcanic quiescence. By contrast, the cherty boles resulted from a 'blanketing' of the lava landscape by extensive ash fall-out which possibly led to the widespread destruction of established fauna and flora. Weathering studies of Shrivastava et al. (2017) on interflow volcanic boles from Mandla lobe, EDVP were primarily focused to trace out paleoenvironment and degree of pedogenic/non-pedogenic conditions that existed during the Deccan volcanism. Owing to limited time intervals during successive eruptions, majority of the bole beds represent incipient to moderate weathering. However, few red and brown bole beds show baking effects rather than pedogenesis. Moreover, comparison of magnetic properties of bole from EDVP and WDVP shows significant differences in the weathering intensity, duration and heating related alterations from the upper flows. But, both EDVP and WDVP bole beds indicate similar first order paleoenvironmental conditions without any major pedogenesis. Crystallographic defects in the smectites of the Jhilmili intertrappean provided evidence of KPB transition induced environmental changes which include global warming, acid rains and $\mathrm{pCO}_{2}$ rise in the atmosphere (Pal et al., 2019b).

\section{Applied Aspects}

\section{$\mathrm{CO}_{2}$ Sequestration in Deccan Basalt}

Shrivastava et al. (2016) reported $\mathrm{CO}_{2}$ sequestration under natural conditions as evidenced by abundant thick limestone and inter-calcarious lithofacies that occur as infra (visibly below lava flows)/inter (between two lava flows) - trappean beds. On the basis of field observations, Shrivastava et al. (2016) considered tholettic basalt lava flows of the Mandla area as a suitable matrix for mineral carbonation reactions and for long-term storage of $\mathrm{CO}_{2}$ as they contain high amount of reactant minerals such as $\mathrm{Ca}, \mathrm{Mg}$ and $\mathrm{Fe}$ rich silicates. Computer based basalt-water- $\mathrm{CO}_{2}$ interaction modeling and laboratory induced reactions under hydrothermal-like conditions form the basis of study. A series of experiments performed at accelerated conditions and post-experimental residues indicate formation of calcite, aragonite, siderite and magnesite. They observed that the basalt dissolution 
rate was faster and reaction is primarily driven by the secondary mineral replacement and growth of minerals. Formation of carbonates is largely due to the breakdown of pyroxene, feldspar and glass.

Kumar et al. (2017) performed Deccan basaltwater- $\mathrm{CO}_{2}$ saturated interaction experiments and numerical simulations under hydrothermal-like conditions. Data revealed appearance of calcite, aragonite, ankerite, huntite and siderite along with the secondary silicates. Moreover, tiny calcite crystals were developed over larger calcite crystals (Fig. 7A), incipient-disordered calcite formed with imperfections on its crystal faces (Fig. 7B) and cubic chabazite crystals surrounded by chlorite grains (Fig. 7C). Formation of disordered rhombic calcite in these experiments is ascribed to a partial carbonation reaction, whereas well-defined rhombic calcite crystal faces (Fig. 7A) formed over basalt is suggestive of a complete carbonation reaction. Experiments run for shorter time periods show formation of secondary carbonates which predominated over the silicates; however, with increased reaction times, carbonates no longer persisted in the system as they were dissolved and replaced by silicates. As a result, thin layer of neo-formed SS form adjacent to the basalt grains. Thus, basalt grains restricted to form carbonates. In this manner, neo-formed SS act as barrier. As a result, basalt-water- $\mathrm{CO}_{2}$ interaction rate is also reduced considerably and limiting availability of $\mathrm{Ca}, \mathrm{Mg}$ and $\mathrm{Fe}$ cation to form carbonates (Kumar and Shrivastava, 2019a). Mixing trends (Kumar et al., 2017) between basalt and $\mathrm{Ca}-\mathrm{Mg}-\mathrm{Fe}$ carbonates and chlorite/smectite were observed in case of phyllosilicates. However, ankerite, calcite and siderite recorded enrichment of (i) $\mathrm{Ca}$, (ii) $\mathrm{Fe}-\mathrm{Mg}$ and (iii) $\mathrm{Fe}$. Secondary silicates formed adjacent to the basalt grains clog basalt-water- $\mathrm{CO}_{2}$ interaction pathways, thus, reduced the amount of $\mathrm{CO}_{2}$ mineralization. Formation of carbonates and secondary silicates is mainly influenced by time; however, pressure, $\mathrm{pH}$ and temperature play subordinate roles. Kumar and Shrivastava (2019b) further validated modeling results by the experiments run in laboratory time framework and resolved that the negative entropy $(\Delta S)$ and enthalpy $\left(\Delta_{\mathrm{f}} \mathrm{H}\right)$ suggested feasibility of plagioclase, pyroxene and magnetite dissolution. The negative

Fig. 7: SEM images of secondary minerals showing (a) stepped growth of calcite and chlorite coatings on basalt, (b) siderite and incipient-disordered rhombic calcite grain with imperfections on crystal faces and (c) chlorite coatings over chabazite grain. Abbreviations: $\mathbf{C a l}=$ Calcite, $\mathbf{C h}=$ Chlorite, $\mathbf{C h b}=$ Chabazite, DB = Deccan Basalt and $\mathrm{Sm}=$ Smectite. Source: Kumar et al. (2017) 
Gibb's free energy $\left(\Delta_{\mathrm{f}} \mathrm{G}\right), \Delta_{\mathrm{f}} \mathrm{H}$ and $\Delta \mathrm{S}$ values for calcite, dolomite and magnesite indicated spontaneous reaction, whereas, positive $\Delta_{\mathrm{f}} \mathrm{G}$ and negative $\Delta_{\mathrm{f}} \mathrm{H}$ and $\Delta \mathrm{S}$ values of the siderite suggested non-spontaneous and opposing reactions. Calcite was the first carbonate mineral to form, but, at a faster rate. Magnetite dissolution begins after a time lag (not initiated along with the plagioclase and pyroxene). Kumar and Shrivastava (2019a) concluded that largely, thermodynamic models do not agree well with the experimental results as numerical models indicate larger carbonate growth. Additionally, transition state theory based models worked well to predict dissolution rates for most of the minerals, but, they over-predict growth of the secondary minerals. Rietveld refinement (RR) results indicate that, weakened $\mathrm{Ca}-\mathrm{O}$ and $\mathrm{C}-\mathrm{O}$ bond length led to calcite degeneration after 80 hours of experiments; therefore, no calcite persisted in the system. Further, the crystal structure of experimentally and naturally formed calcite and chabazite was alike to each other (Kumar and Shrivastava, 2019c). The mass balance estimates after each experiment run revealed that the maximum $30.75 \mathrm{~mol} \%$ of ions from parent basalt reacted during carbonation reaction. As a result, $22.88 \mathrm{~mol} \%$ of $\mathrm{CO}_{2}$ mineralized in the form of carbonates (such as calcite and dolomite) at $100^{\circ} \mathrm{C}$ under 5 bar $\mathrm{CO}_{2}$ for $70 \mathrm{~h}$ of experiment (Kumar and Shrivastava, 2019d).

\section{Impact glass and Obsidian: A Natural Analogue of Nuclear Waste Glass}

Rani et al. (2015) and Kumar et al. (2019) discussed Deccan basaltic glass (associated with the differentiation centers of vast basaltic magmas) for its suitability as a standad reference for radioactive waste containment. The suitability primarily depends upon alteration behavior under hydrothermal-like conditions. Alteration results when compared to the naturally altered glass show partial to complete release of all the ions; however, abundant release of $\mathrm{Si}$ and $\mathrm{Na}$ ions is noticed. Altered residue shows morphologies of smectite, montmorillonite and illite inside as well as outside of the secondary layers. Octahedral cation occupancies of smectite were found consistent with the dioctahedr alsmectite. The secondary layer composition indicates retention for $\mathrm{Si}, \mathrm{Al}$, and $\mathrm{Mg}$ cations, indicating their fixation, but remarkably high retention of $\mathrm{Ti}, \mathrm{Mn}$ and $\mathrm{Fe}$ cation suggested release of very small amount of these elements into the solution. By evolution of secondary layer and retention of less soluble ions, the obstructive effect of secondary layer increases and constant release rate initiated slowly to diminish with time. Process of devitrification along the cracks and formation of spherulite-like structures, yellowish brown palagonite, chlorite, calcite, zeolite and finally white coloured clay minerals largely correspond to altered obsidian that existed in the natural environment since inception ( $66 \mathrm{Ma}$ ago). Moreover, low elemental release rate from the glass matrix is suggestive of high order of chemical durability of glass. Obsidian, a natural analogue for the nuclear waste glass is durable enough to withstand natural environmental conditions for a period of $\sim 300$ years till the radioactivity of $\mathrm{Ce}$ isotopes is ceased. The chemico-mineralogical attributes of the obsidian are analogous to radioactive waste form; therefore, obsidian is suitable for safe disposal of high-level nuclear waste in the geological repository. Process and extent of palagonitization and the formation of smectite are comparable to the experimentally altered as well as naturally weathered glass. The microtextures and microchemistry of altered glass revealed evolutionary changes partly to complete alteration and growth of palagonite, smectite, illite, montmorillonite, calcite and zeolite.

\section{Future Directions}

Present review discusses several important findings covering almost all the aspects related to Deccan volcanism, however, a few important issues that remain to be addressed include:

1. Most of the new bulk, mineral chemistry, Nd$\mathrm{Sr}-\mathrm{Pb}$ isotopic and ${ }^{40} \mathrm{Ar}-{ }^{39} \mathrm{Ar}$ age data-sets restricted to differentiation centers, located in the western part of Deccan volcanic province; however, such data is rare for the peripheral areas.

2. Comprehensive flow by flow stratigraphic framework, age and duration of volcanism for the peripheral areas and sub-surface KoynaWarna-Panchgani sections are required with special reference to their stratigraphic correlations with the main DVP to understand source, eruption mechanism, and rate of host magma ascended, age and duration of Deccan volcanism. 
3. To find out possible link (if any) between the Sagar GPB and the type GPB section of the western DVP.

4. Parental magmas and the fractionation trends for various basalt suites required to be assessed particularly for the central and peripheral areas.

5. Mechanism to understand derivation of alkaline and tholeiitic magma from the mantle sources

6. To understand geodynamic setting of the magma suites with contrasting characters.

7. Lherzolite mantle equilibration trends need thorough investigations.

8. Timing of the dykes such as pre, syn or post to the lava flows is required to be resolved.

9. Inconsistency in the ages with southward migration of volcanism due to northward journey of the Indian plate above the Reunion hotspot need to be re-visited.

10. More age data is required to ascertain accurate timing of the periodically replenished alkaline magma with respect to Mundwara and SarnuDandali complexes.

11. Flow-by-flow palaeomagnetic measurements and magnetostratigraphic correlation are required to understand structural complexities with special reference to palaeo-surfaces and faulting due to post-Deccan isostatic adjustments.

12. To find out possible link between the main phases of Deccan volcanic eruptions and the timing of the $\mathrm{K} / \mathrm{Pg}$ transition events.

13. To understand late Cretaceous palaeoenvironmental implications (for the fauna and flora), pyroclastic input needs to be accessed thoroughly.

14. To establish Chicxulub impact signature as a precise stratigraphic reference point within the Deccan stratigraphy.

\section{Conclusions}

Present review on late Cretaceous Deccan volcanism and related issues concluded with the following remarks:
1. Petrography, mineral chemistry, whole-rock major, trace elemental and $\mathrm{Nd}-\mathrm{Sr}-\mathrm{Pb}$ isotopic data in conjunction with the ${ }^{40} \mathrm{Ar}-{ }^{39} \mathrm{Ar}$ ages, revealed that the Deccan Traps associated silicic magmatism post-dates flood basalt eruptions. The Barda granophyre intrusions pre-dated intense and most prolific 66-65 Ma Deccan flood basalt phase by 3 to $4 \mathrm{Ma}$, thus, entailed a total duration of $\sim 8 \mathrm{Ma}$. These observations are in conformity with the finding of Salil et al. (1997) and supportive of prolong duration of the Deccan volcanism (Shrivastava et al., 2012).

2. Moreover, the 69-68 Ma Barda granophyre plutonism took place within-plate tectonic setting (Bhattacharya and Yatheesh, 2015). The voluminous basalt fractionation-derived silicic magmatism in Barda and Alech complexes suggested temporal evolution of the Deccan flood basalt volcanism. Further, magma evolution represents a pulsating mantle melting regime, where such activity continued for $>1 \mathrm{Ma}$. The Deccan volcanism is constrained by these ages and belongs to the magnetic chrons C31-C29. But, recalculated ages pointing towards initiation of the first phase of alkaline Deccan magmatism in Sarnu and Mundwara complexes in northern Deccan (Basu et al., 1993) was coincidental with the boundary between the magnetic chrons C31r and C31n.

3. New U-Pb zircon age data (Schoene et al., 2019) recognizes four major eruptive phases (Fig. 6); each lasted for $\leq 100 \mathrm{ka}$ and separated by periods of relative volcanic quiescence. Moreover, one of the phases initiated tens of thousands of years prior to both bolide impact and the $\mathrm{K} / \mathrm{Pg}$ extinction. Coincidental with the second major eruptive phase, Poladpur Formation eruption began tens of thousands of years before, but peaked out at $\mathrm{K} / \mathrm{Pg}$ mass extinction event which continued after it, but in a subdued manner. Finding out Chicxulub impact signature (if any) may provide a precise stratigraphic reference point within the Deccan stratigraphy.

4. Stratigraphically, widespread dissolution event, climatic cooling, followed by the late Maatrichtian global warming (Punekar et al., 2016) attendant 
to Deccan volcanism induced ocean acidification and high stress environments.

5. Both modeling and experimental results revealed that maximum amount of carbonation of Deccan basalt is possible under short-term hydrothermallike conditions. Suitability of silicic phase for nuclear waste disposal is also discussed.

\section{References}

Alexander P O and Purohit M K (2019) Giant Plagioclase Basalt from the Deccan volcanic province (DVP), Sagar district, Madhya Pradesh, India: First report and implications Jour Geological Society of India 94 139-141

Basavaiah N, Satyanarayana K V V, Deenadayalan K and Prasad J N (2018) Does Deccan volcanic sequence contain more reversals than the three-Chron N-R-N flow magnetostratigraphy?-A palaeomagnetic evidence from the dyke-swarm near Mumbai Geophysical Jour Intern 213 1503-1523

Basu A R, Renne P R, Dasgupta D K, Teichmann F, Poreda R J (1993) Early and late igneous pulses and high $3 \mathrm{He}$ plume origin for the Deccan flood basalts Science 261 902-906

Bhattacharya G C and Yatheesh V (2015) Plate-tectonic evolution of the deep ocean basins adjoining the western continental margin of India - a proposed model for the early opening scenario Petroleum Geosciences: Indian Contexts Edition Ch1Chapter Pub Springer International Publishing Switzerland doi: 10.1007/978-3-319-03119-4_1

Burgess S (2019) Deciphering mass extinction triggers improved radioisotope dates help to illuminate the causes of mass extinctions Science 363 815-816

Cande S C and Kent D V (1995) Revised calibration of the geomagnetic polarity time scale for the Late Cretaceous and Cenozoic Jour Geophysical Research 100 6093-6095

Chatterjee N and Sheth H (2015) Origin of the Powai ankaramite, and the composition, P-T conditions of equilibration and evolution of the primary magmas of the Deccan tholeiites Contributions to Mineralogy and Petrology 169 1-24 DOI 10.1007/s00410-015-1125-8

Chenming L and Demin Y (2018) Study on the relationship between Deccan LIPs and Chicxulub crater based on "collisions aggregation effect" Earth Sciences 7 64-73

Cucciniello C, Choudhary A K, Pande K and Sheth H (2018) Mineralogy, geochemistry and ${ }^{40} \mathrm{Ar}-{ }^{39} \mathrm{Ar}$ geochronology of the Barda and Alech complexes, Saurashtra, northwestern Deccan traps: Early silicic magmas derived

\section{Acknowledgement}

JPS acknowledges Ministery of Earst Sciences (MoES), Government of India, New Delhi for financial assistance in the form of a Project Grant [MoES/ P.O.(Seismo)/1(230/2014)].

by flood basalt fractionation Geological Magazine doi.org/ $10.1017 / \mathrm{S} 0016756818000924$

Ernst R E (2014) Large igneous provinces Cambridge University Press 667

Font E, Adatte T, Sial A N, Drude de Lacerda L, Keller G and Punekar J (2016) Mercury anomaly, Deccan volcanism, and the end-Cretaceous mass extinction Geological Society of America 44 171-174

Gradstein F M, Ogg J G, Schmitz M D and Ogg G M (2012) The Geologic Time Scale 2012 Elsevier, Amsterdam

Keller G, Mateo P, Punekar J, Khozyem H, Gertsch B, Spangenberg J, Bitchong A and Adatte T (2017) Environmental changes during the Cretaceous-Paleogene mass extinction and Paleocene-Eocene thermal maximum: Implications for the Anthropocene Gondwana Research 56 69-89

Kumar R and Shrivastava J P (2009) Geochemistry of basic dykes from Betul-Jabalpur area in the Deccan volcanic province Jour Geological Society of India 74 95-107

Kumar A, Shrivastava J P and Pathak V (2017) Mineral carbonation reactions under water-saturated, hydrothermal-like conditions and numerical simulations of $\mathrm{CO}_{2}$ sequestration in tholeiitic basalt of the eastern Deccan volcanic province, India Applied Geochemistry 84 87-104

Kumar A and Shrivastava J P (2019a), Secondary silicates as barrier for carbon capture and storage in Deccan basalt Acta Geologica Sinica doi: 10.1111/1755-6724.14291

Kumar A and Shrivastava J P (2019b) Thermodynamic modelling and experimental validation of $\mathrm{CO}_{2}$ mineral sequestration in Mandlabasalt of the eastern Deccan volcanic province, India Jour Geological Society of India 93 269-277

Kumar A and Shrivastava J P (2019c) Long-term $\mathrm{CO}_{2}$ capture induced calcite crystallographic changes in Deccan basalt, India Environmental Earth Sciences doi.org: 10.1007/ s12665-019-8378-x

Kumar, A and Shrivastava, J P (2019d) Carbon capture induced changes in Deccan basalt: A mass balance approach. Greenhouse Gases: Science and Technology doi: 10.1002/ 
ghg. 1923

Kumar A, Shrivastava J P, Meenakshi, Chopra S, Chakraborty S (2019) Impact glass applied as a standard for long-term performance assessment of Na-Ba borosilicate glass forms in geological environment. Applied Geochemistry doi.org/ 10.1016/j.apgeochem.2019.104477

Mishra S, Misra S, Vyas D, Nikalje D, Warhade A and Roy S (2017) A 1251m-thick Deccan flood basalt pile recovered by scientific drilling in the Koyna region, western India Jour Geological Society of India 90 788-794

Mukhopadhyay S K, Pal S and Shrivasatava J P (2017) Comments on the paper published by Sial et al (2016), Mercury enrichments and $\mathrm{Hg}$ isotopes in Cretaceous-Paleogene boundary successions: Links to volcanism and palaeoenvironmental impacts Cretaceous Research 66 6061

Natali C, Beccaluva L, Bianchini G and Siena F (2016) Comparison among Ethiopia-Yemen, Deccan, and Karoo continental flood basalts of central Gondwana: Insights on lithosphere versus asthenosphere contributions in compositionally zoned magmatic provinces. The Geological Society of America Special Paper 526

Pal S, Shrivastava J P and Mukhopadhyay S K (2015a) Polycyclic aromatic hydrocarbon compound excursions and $\mathrm{K} / \mathrm{Pg}$ transition in the late Cretaceous-early Palaeogene succession of the Um Sohryngkew river section, Meghalaya Current Science 109 1140-1150

Pal S, Shrivastava J P and Mukhopadhyay S K (2015b) Physils and organic matter-basepalaeoenvironmental records of the $\mathrm{K} / \mathrm{Pg}$ boundary transition from the late Cretaceous-early Palaeogene succession of the Um-Sohryngkew River section of Meghalaya, India Chemie der Erde 75 445-463

Pal S, Srivastava S, Shrivastava J P (2019a) Environmental effects of Deccan volcanism on biotic transformations and attendant Cretaceous/Paleogene boundary mass extinction in the Indian subcontinent: Organo-molecular evidence. GSA special papers Mass Extinctions, Volcanism, and Impacts: New Developments, Ed Thierry Adatte; David P.G. Bond; Gerta Keller, doi:https://doi.org/10.1130/ 2019.2544(07)

Pal S, Meenakshi, Kumar A, Shrivastava J P and Dev A B (2019b) Evidence of K/PB transition linked crystallographic defects in the smectites associated with the Jhilmiliintertrappean bed, Central India Jour Geological Society of India 94 142158

Pande K, Vadakkeyakath Y and Sheth $\mathrm{H}(2017){ }^{40} \mathrm{Ar} /{ }^{39} \mathrm{Ar}$ dating of theMumbai tholeiites and Panvel flexure: intense 62.5Ma onshore-offshore Deccan magmatism during India-
Laxmi Ridge-Seychelles breakup Geophysical Jour International 210 1160-1170

Parisio L, Jourdan F, Marzoli A, Melluso L, Sethna S F and Bellieni $\mathrm{G}(2016){ }^{40} \mathrm{Ar} /{ }^{39} \mathrm{Ar}$ ages of alkaline and tholeiitic rocks from the northern Deccan traps: Implications for magmatic processes and the K-Pg boundary Jour Geological Society 173 679-688

Pathak V, Patil S K and Shrivastava J P (2016) Tectonomagmatic setting of lava packages in the Mandla lobe of the eastern Deccan volcanic province, India: palaeomagnetism and magnetostratigraphic evidence Geological Society, London, Special Publications 445 69-94, doi.org/10.1144/ SP445.3

Petersen S V, Dutton A and Lohmann K C (2016) End-Cretaceous extinction in Antarctica linked to both Deccan volcanism and meteorite impact via climate change Nature Communications 712079 doi: 10.1038/ncomms12079

Prasanth M P M, Hari K R and Santosh M (2019) Tholeiitic basalts of Deccan large igneous province, India: An overview Geological Jour 1-14doi: 10.1002/gj.3497

Punekar J, Keller G, Khozyem H M, Adatte T, Font E and Spangenberg J (2016) A multi-proxy approach to decode the end-Cretaceous mass extinction Palaeogeography Palaeoclimatology Palaeoecology 441 116-136doi.org/ $10.1016 /$ j. palaeo.2015.08.025

Rani N, Shrivastava J P and Bajpai R K (2015) Natural glass from Deccan volcanic province: an analogue for radioactive waste form International Jour Earth Science doi 10.1007/s00531015-1244-5

Ray A, Hatui K, Paul D K, Sen G, Biswas S K and Das B (2016) Mantle xenolith-xenocryst-bearing monogenetic alkali basaltic lava field from Kutch Basin, Gujarat, Western India: Estimation of magma ascent rate Jour Volcanology and Geothermal Research 312 40-52

Renne P R, Sprain C J, Richards M A, Self S, Vanderkluysen L and Pande K (2015) State shift in Deccan volcanism at the Cretaceous-Paleogene boundary, possibly induced by impact Science $\mathbf{3 5 0} 6256$

Richards M A, Alvarez W, Self S, Karlstrom L, Renne P R, Manga M, Sprain C J, Smit J, Vanderkluysen L and Gibson S A (2015) Triggering of the largest Deccan eruptions by the Chicxulub impact Geological Society of America 127 1507-1520

Salil M S, Shrivastava J P and Pattanayak S K (1997) Similarities in the mineralogical and geochemical attributes of detrital clays of Maastrichtian Lameta beds and weathered Deccan basalt, Central India Chemical Geology 136 25-32

Schoene B, Samperton K M, Eddy M P, Keller G, Adatte T, Bowring S A, Khadri S F R and Gertsch B (2015) U-Pb 
geochronology of the Deccan traps and relation to the endCretaceous mass extinction Science 347 182-184

Schoene B, Eddy M P, Samperton K M, Keller C B, Keller G, Adatte T and Khadri S F R (2019) U-Pb constraints on pulsed eruption of the Deccan Traps across the endCretaceous mass extinction Science 363 862-866

Sial A N, Chen J, Lacerda L D, Frei R, Tewari V C, Pandit M K, Gaucher C, Ferreira V P, Cirilli S, Peralta S, Korte C, Barbosa J A and Pereira N S (2017) Mercury enrichment and $\mathrm{Hg}$ isotopes in Cretaceouse Paleogene boundary successions: Links to volcanism and palaeoenvironmental impacts Cretaceous Research 66 60-81

Sinha D K, Som A and Roy S (2017) The subsurface megascopic characteristics of basalt and basement rocks from KoynaWarna area of Maharashtra, India Jour Geological Society of India 90 761-768

Sheth H (2016) Giant plagioclase basalts: Continental flood basaltinduced remobilization of anorthositic mushes in a deep crustal sill complex Geological Society of America Bulletin 128 916-925 doi:10.1130/B31404.1

Sheth H, Pande K, Vijayana A, Sharma K K and Cucciniello C (2017) Recurrent Early Cretaceous, Indo-Madagascar (89$86 \mathrm{Ma})$ and Deccan (66 Ma) alkaline magmatism in the Sarnu-Dandali complex, Rajasthan: ${ }^{40} \mathrm{Ar} /{ }^{39} \mathrm{Ar}$ age evidence and geodynamic significance Lithos 284-285 512-524

Sheth H, Vanderkluysen L, Demonterova E I, Ivanov A V and Savatenkov V M (2018) Geochemistry and ${ }^{40} \mathrm{Ar} /{ }^{39} \mathrm{Ar}$ geochronology of the Nandurbar Dhule mafic dyke swarm: Dyke sill flow correlations and stratigraphic development across the Deccan flood basalt province Geological Jour 1-20. DOI: $10.1002 /$ gj.3167

Shrivastava J P, Ahmad M and Raju Kumar (2008) Petrography, composition and petrotrogenesis of the basalts of theChakhla - Delakhari intrusive complex from the eastern Deccan volcanic province, India Indian Dykes: Geochemistry, Geophysics and Geochronology, Norosa Pub. House Pvt Ltd 83-109

Shrivastava J P, Mukhopadhyay S K and Pal S (2012) Chemico- mineralogical attributes of clays from bole horizons in the early Cretaceous Sylhet Traps of Meghalaya: palaeoenvironmental inferences Current Science 102 332338

Shrivastava J P, Mahoney J J and Kashyap M (2014) Trace elemental and $\mathrm{Nd}-\mathrm{Sr}-\mathrm{Pb}$ isotopic compositional variation in 37 lava flows of Mandla lobe and their chemical relation to the western Deccan stratigraphic succession, India Mineralogy Petrology 801-817 doi 10.1007/s00710-0140337-3

Shrivastava J P, Duncan R A and Kashyap M (2015) Post-K/PB younger ${ }^{40} \mathrm{Ar}-{ }^{39} \mathrm{Ar}$ ages of the Mandla lavas: Implications for the duration of the Deccan volcanism Lithos 224-225 214-224.

Shrivastava J P, Rani N and Pathak V (2016) Geochemical modeling and experimental studies on mineral carbonation of primary silicates for long-term immobilization of $\mathrm{CO}_{2}$ in basalt from the eastern Deccan volcanic province Jour Indian Geophysical Union (Special Volume) $142-58$

Shrivastava J P,Kumar R and Rani N (2017) Feeder and post Deccan Trap dyke activities in the northern slope of the Satpura mountain: Evidence from new ${ }^{40} \mathrm{Ar}-{ }^{39} \mathrm{Ar}$ ages Geoscience Frontiers doi: 10.1016/j.gsf.2016.04.001

Sprain C J, Renne P R, Vanderkluysen L, Pande K, Self S and Mittal T (2019) The eruptive tempo of Deccan volcanism in relation to the Cretaceous-Paleogene boundary Science $363866-870$

Vedanti N, Malkoti A, Pandey O P and Shrivastava J P (2018) Ultrasonic P- and S-wave attenuation and petrophysical properties of Deccan flood basalts, India, as revealed by borehole studies Pure and Applied Geophysics 175 29052930

Widdowson M, Walsh J N and Subbarao K V (2015) The geochemistry of Indian bole horizons: palaeoenvironmental implications of Deccan intravolcanicpalaeosurfaces: Recognition, reconstruction and palaeoenvironmental interpretation Geological Society Special Publication 120 269-281. 